\title{
Bone Marrow and Peripheral Blood AML Cells Are Highly Sensitive to CNDAC, the Active Form of Sapacitabine
}

\author{
Sucheta Jagan, ${ }^{1,2,3}$ Laura A. Paganessi, ${ }^{1,2,3}$ Robin R. Frank, ${ }^{1,2,3}$ Parameswaran Venugopal, 2,3 \\ Melissa Larson, ${ }^{2,3}$ and Kent W. Christopherson II ${ }^{1,2,3,4}$ \\ ${ }^{1}$ Section of Bone Marrow Transplant and Cell Therapy, Rush University Medical Center, 1725 West Harrison Street, \\ Chicago, IL 60612, USA \\ ${ }^{2}$ Rush University Cancer Center, 1725 West Harrison Street, Chicago, IL 60612, USA \\ ${ }^{3}$ Section of Hematology, Rush University Medical Center, 1725 West Harrison Street, Chicago, IL 60612, USA \\ ${ }^{4}$ Department of Anatomy and Cell Biology, Rush University Medical Center, 1725 West Harrison Street, Chicago, IL 60612, USA
}

Correspondence should be addressed to Kent W. Christopherson II, kent_christopherson@rush.edu

Received 18 June 2012; Accepted 4 August 2012

Academic Editor: Seiji Fukuda

Copyright (c) 2012 Sucheta Jagan et al. This is an open access article distributed under the Creative Commons Attribution License, which permits unrestricted use, distribution, and reproduction in any medium, provided the original work is properly cited.

\begin{abstract}
Achieving improvements in survival and reducing relapse remains a challenge in acute myelogenous leukemia (AML) patients. This study evaluated the in vitro efficacy of the active form of novel agent sapacitabine, CNDAC, compared to current chemotherapeutic drugs Ara-C and mitoxantrone using two AML cell lines, HL-60 (promyelocytic) and THP-1 (monocytic), as well as bone marrow $(\mathrm{BM})$ and peripheral blood $(\mathrm{PB})$ cells collected from AML patients. Cell lines were exposed to compound for 3-6 days and primary cells for 4 days. The viability of primary cells was additionally evaluated 3, 7, and 31 days after removal of tested compound to determine the durability of the response. Our studies indicate that CNDAC and mitoxantrone have a greater impact on viability than ara-C in primary AML cells and AML cell lines. CNDAC is more effective at reducing viability and inducing apoptosis than ara-C at equivalent concentrations in the THP-1 cell line, which is defined as displaying resistance to ara-C. As sapacitabine has shown in vivo activity at clinically achievable doses, future studies are warranted to assess the potential for combining it with ara-C and/or mitoxantrone, with an emphasis on cells and patients insensitive to ara-C treatment.
\end{abstract}

\section{Introduction}

Acute myeloid leukemia (AML) therapy is continually challenged by high incidences of disease relapse and patient mortality. The overall 5-year survival rate for AML is 30 $40 \%$ for patients $>45$ years and $<10 \%$ for patients over 60 years [1]. However, the long-term event free survival rate of these patients is only $20-50 \%[2,3]$. The current AML therapy, " $7+3$ " regimen with cytarabine (ara-C) and an anthracycline such as daunorubicin, idarubicin, or the synthetic anthracenedione mitoxantrone, has been the standard of care for decades. The nucleoside analog ara-C forms the backbone of AML treatment, either in low doses during induction therapy, or at high doses for maintenance after remission $[4,5]$. Although high dose therapy has been shown to improve survival, $60-70 \%$ of patients relapse and eventually die due to disease progression $[4,6]$. Moreover, there are patients who are nonresponsive to ara- $\mathrm{C}$ and many elderly AML patients cannot tolerate the regime and hence are not eligible for intensive chemotherapy. Novel therapeutic approaches are therefore required.

Nucleoside analogs, such as ara-C, represent a major group of antileukemic agents [5]. They are cell cycledependent cytotoxic agents that incorporate into the growing DNA strand forcing chain termination and inhibition of DNA synthesis. They are activated by the sequential addition of phosphates, firstly to the $5^{\prime}$ monophosphates form by the enzyme deoxycytidine kinase (dCK), and subsequently by other cellular enzymes which convert them into the di- and tri- phosphate forms, in preparation for incorporation into DNA [7]. Studies have indicated that resistance to nucleoside analogs mainly arise due to deamination by the enzyme 
TABle 1: Patient clinical characteristics.

\begin{tabular}{|c|c|c|c|c|c|c|c|c|c|c|c|}
\hline $\begin{array}{l}\mathrm{Pt} \\
\text { ID } \\
\text { number }\end{array}$ & FAB & $\begin{array}{l}\text { WBC } \\
(\mathrm{Th} / \mathrm{ul})\end{array}$ & $\begin{array}{l}\mathrm{Hb} \\
(\mathrm{g} / \mathrm{dl})\end{array}$ & $\begin{array}{c}\text { Plt } \\
(\mathrm{Th} / \mathrm{ul})\end{array}$ & Cytogenetics & FISH & $\begin{array}{l}\text { Flt-3 } \\
\text { ITD }\end{array}$ & $\begin{array}{l}\text { Flt-3 } \\
\text { TKD }\end{array}$ & NPM & $\begin{array}{c}\% \\
\text { Blasts } \\
\text { PB }\end{array}$ & $\begin{array}{c}\% \\
\text { Blasts } \\
\text { BM }\end{array}$ \\
\hline Normal & range & $4-10$ & $13.5-17.5$ & $150-450$ & & & & & & - & $\leq 5$ \\
\hline 005 & M1 & 77 & 8.4 & 37 & Trisomy 13 & $\begin{array}{l}\mathrm{t} / \operatorname{del}(11)(\mathrm{q} 23) \& \\
\operatorname{del}(20)(\mathrm{q} 12)\end{array}$ & ND & ND & - & 88.9 & 98.5 \\
\hline 038 & M4Eo & 27.06 & 8.5 & 57 & Inv 16 & ND & - & - & ND & ND & 71.8 \\
\hline 042 & ND & 43.03 & 8.9 & 89 & Normal & ND & + & - & + & 53 & 56.6 \\
\hline 045 & M2 & 93.75 & 10.2 & 50 & Normal & ND & - & + & - & 21.5 & 99 \\
\hline 059 & ND & 90.78 & 7.2 & 35 & Complex & ND & ND & ND & ND & 90 & 90 \\
\hline
\end{tabular}

FAB: French-American-British classification; WBC: white blood cell; Hb: hemoglobin level; Plt: platelet level; FISH: fluorescence in situ hybridization; Flt-3: FMS-like tyrosine kinase 3; ITD: internal tandem duplications; TKD: tyrosine kinase domain; NPM: nucleophosmin; ND: not determined.

cytidine deaminase (CDA) or due to the activity of the cytoplasmic enzyme $5^{\prime}$ nucleotidase, which dephosphorylates $5^{\prime}$ monophosphate products, opposing dCK activity [8]. Other resistance mechanisms include overexpression of transmembrane efflux pumps and reduced expression of topoisomerases [9]. Novel nucleoside analogs are mainly the result of minor structural modifications of existing drugs in an attempt to improve activity and suppress resistance [5].

Mitoxantrone is a synthetic anthracenedione that was developed as an analog to doxorubicin to reduce drug associated cardio-toxicity [10]. It is widely used in the treatment of previously untreated and relapsed AML patients [11]. Mitoxantrone is known to induce cell death by multiple mechanisms. At the molecular level, it markedly affects the activity of the enzyme topoisomerase II and causes DNA single and double strand breaks. The formation of a stable topoisomerase-DNA cleavable complex prevents rejoining of strand breaks. It intercalates stacked bases of DNA and can also bind to DNA via electrostatic cross-linking interactions. Oxidative activation of mitoxantrone generates free radicals that induce nonprotein associated strand breaks [11, 12]. At the cellular level, the drug is shown to be active as an immunosuppressant, affecting the activity of macrophages, $\mathrm{T}$ and $\mathrm{B}$ cells [10]. Therefore, mitoxantrone is active in both proliferating and nonproliferating cells. 2' -C-Cyano$2^{\prime}$-deoxy- 1 - $\beta$-d-arabino-pentofuranosylcytosine (CNDAC), the major metabolite of oral drug sapacitabine, is a nucleoside analog that is structurally related to ara-C and gemcitabine $[13,14]$. The major difference is the addition of a cyano group replacing the $2^{\prime}$ hydrogen of the sugar moiety [14]. Ara-C and other nucleoside analogs induce cell cycle arrest in the S-phase. CNDAC, however, induces cell cycle arrest in the G2 phase following a delayed $S$ phase [15]. Unlike ara-C, it does not cause chain termination at the site of incorporation. After additional elongation, the strong electrophilic property of the cyano group rearranges the nucleotide such that it lacks a free $3^{\prime} \mathrm{OH}$ group $[13,16]$. This resultant single strand break is minimally repaired by the cell's excision repair mechanism [17]. Replication results in a double strand break, eventually terminating DNA synthesis. In order to test the in vitro efficacy of CNDAC, this study compared CNDAC to conventional drugs, ara-C and mitoxantrone, in the promyelocytic cell line HL-60, which is known to be sensitive to ara-C, the monocytic cell line THP1 , known to be less sensitive to ara-C, and peripheral blood and bone marrow cells from 5 AML patients.

\section{Materials and Methods}

2.1. Cell Lines. AML cell lines, HL-60 and THP-1, were obtained from ATCC (Manassas, VA) and cultured in RPMI 1640 medium (with phenol red) (Thermo Scientific Hyclone, Logan, UT) supplemented with 10\% fetal bovine serum (Thermo Scientific Hyclone), $100 \mathrm{U} / \mathrm{mL}$ penicillin $/ 100 \mu \mathrm{g} / \mathrm{mL}$ streptomycin solution (Thermo Scientific Hyclone), and $2 \mathrm{mM}$ L-Glutamine (Thermo Scientific Hyclone). Cells were cultured at $37^{\circ} \mathrm{C}, 5 \% \mathrm{CO}_{2}$, and $100 \%$ humidity. Cells were in the logarithmic growth phase at the beginning of all experiments.

M2-10B4 stromal cells were purchased from ATCC and cultured in RPMI 1640 media. Stromal layers were prepared by irradiating cells at 80 Gy and plating them on gelatinized 24 well plates at a concentration of $5 \times 10^{4}$ cells/well. Wells were gelatinized by adding $0.1 \%$ gelatin in water (EMD Millipore, Billerica, MA) to each well and incubating for 6 hours. The M2-10B4 stromal layer was incubated at $37^{\circ} \mathrm{C}$, $5 \% \mathrm{CO}_{2}$, and $100 \%$ humidity for at least 24 hours before addition of AML cells.

2.2. Patient Samples. Peripheral blood (PB) and bone marrow (BM) specimens were obtained from 5 AML patients with informed consent on an IRB approved protocol in accordance with the Declaration of Helsinki. Of these patients, 3 were newly diagnosed and 2 had relapsed. The 2 relapsed patients had trisomy 13 and complex karyotypes, respectively. All other patients had normal cytogenetics. Total WBC counts of the patients ranged from 27.06 to $93.75 \mathrm{~K} / \mu \mathrm{L}$ with 56.6 to $98.5 \%$ blasts in the bone marrow. Additional clinical information is provided in Table 1 . All specimens were collected prior to treatment. Peripheral blood was collected in heparinized vacutainer tubes and BM aspirates 
were collected in heparinized syringes. Mononuclear cell (MNC) fractions were obtained by density gradient centrifugation using Ficoll-Paque Plus (GE Healthcare, Piscataway, $\mathrm{NJ})$. Cells were frozen and stored in liquid nitrogen and thawed before use. PB MNCs were treated with drug while in suspension, and BM MNCs were treated while in a coculture system with the mouse stromal cell line M2-10B4. Suspension medium was IMDM (Thermo Scientific Hyclone) supplemented with $20 \% \mathrm{FBS}, 100 \mathrm{U} / \mathrm{mL}$ penicillin $/ 100 \mu \mathrm{g} / \mathrm{mL}$ streptomycin, $2 \mathrm{mM}$ L-Glutamine, $100 \mathrm{ng} / \mathrm{mL}$ SCF (Stem Cell Technologies, Vancouver, Canada), and $50 \mathrm{ng} / \mathrm{mL}$ IL3 (EMD Millipore, Billerica MA). Co-culture media was the same as suspension medium with the addition of $1 \mu \mathrm{M}$ hydrocortisone (Sigma Aldrich, St. Louis, MO).

2.3. Drugs, Treatment, and Culture Conditions. Cytarabine (ara-C) was purchased from Bedford Laboratories (Bedford, $\mathrm{OH}$ ) and mitoxantrone from Mayne Pharma Limited (Mulgrave, Australia). CNDAC was kindly provided by Cyclacel Ltd. (Dundee, UK). Stock concentrations for ara$\mathrm{C}(100 \mathrm{mM})$ and mitoxantrone $(1 \mathrm{mM})$ were made in Dulbecco's Phosphate-Buffered Saline (DPBS) and stored at $-80^{\circ} \mathrm{C}$ while CNDAC $(100 \mathrm{mM})$ was dissolved in dimethylsulphoxide (DMSO) (Sigma Aldrich) and stored at $-20^{\circ} \mathrm{C}$. Working stocks of drugs were made in media.

Cell lines (HL-60 and THP-1) were treated in suspension in 48 well plates at seeding densities of $0.05 \times 10^{6}$ cells $/ \mathrm{mL}$ (low) or $0.5 \times 10^{6}$ cells $/ \mathrm{mL}$ (high). Cells were treated with ara-C or CNDAC at $0.5,1,2,3,4,5$, and $10 \mu \mathrm{M}$ and mitoxantrone at $0.0025,0.005,0.01,0.02,0.03,0.04$, and $0.05 \mu \mathrm{M}$ in triplicate at $37^{\circ} \mathrm{C}, 5 \% \mathrm{CO}_{2}$, and $100 \%$ humidity. Appropriate untreated controls were included. Cells were analyzed 3, 4, 5, and 6 days posttreatment.

$1 \times 10^{6}$ primary $\mathrm{BM}$ and $\mathrm{PB}$ cells were treated with $1 \mu \mathrm{M}$ (low), $10 \mu \mathrm{M}$ (medium), and $100 \mu \mathrm{M}$ (high) of ara-C or CNDAC or $0.005 \mu \mathrm{M}$ (low), $0.05 \mu \mathrm{M}$ (medium) and $0.5 \mu \mathrm{M}$ (high) mitoxantrone in 24 well plates at $37^{\circ} \mathrm{C}, 5 \% \mathrm{CO}_{2}$, and $100 \%$ humidity for 4 days. Appropriate untreated controls were included. Postdrug treatment, both $\mathrm{PB}$ and BM nonadherent cells were washed to remove compound, replated on M2-10B4 stromal layers, and reincubated at $37^{\circ} \mathrm{C}, 5 \%$ $\mathrm{CO}_{2}, 100 \%$ humidity. Cells were analyzed immediately posttreatment and following 3,7 , and 31 days postdrug removal.

2.4. Alamar Blue Assay. The Alamar Blue assay was performed to determine drug $\mathrm{IC}_{50}$ values in AML cell lines. HL-60 and THP- 1 cells were plated on 96 well flat bottom plates at $5 \times 10^{3}$ cells/well. Cells were incubated at $37^{\circ} \mathrm{C}, 5 \%$ $\mathrm{CO}_{2}, 100 \%$ humidity for 24 hours before addition of drugs. Cells were treated with ara-C, CNDAC and mitoxantrone in triplicate at 10 concentrations between 0.005 and $100 \mu \mathrm{M}$. Plates were reincubated for 72 hours after addition of drugs. After 72 hours, Alamar Blue (AbD Serotec, Oxford, UK) was added to all wells at a final concentration of $10 \%$, and plates were returned to the incubator for 8 hours before absorbance was read on the spectrometer (SpectraMax M5, Molecular Devices, Sunnyvale, CA) at wavelengths of $570 \mathrm{~nm}$ and $600 \mathrm{~nm}$. Cell proliferation was determined by calculating the reduction of Alamar Blue. The equation used was as follows:

\%Reduction in Alamar Blue

$$
=\frac{\left[\left(O_{600} \times A_{570}\right)-\left(O_{570} \times A_{600}\right)\right]}{\left[\left(R_{570} \times N_{600}\right)-\left(R_{600} \times N_{570}\right)\right]} \times 100 .
$$

$O$ and $R$ are the molar extinction coefficients of Alamar Blue in its oxidized and reduced form, where $O_{600}=11726$, $O_{570}=80586, R_{570}=155677$ and $R_{600}=14652 . N$ is the absorbance of the negative control well.

$\%$ Inhibition was calculated using the equation:

$$
\begin{aligned}
& {\left[1-\left(\frac{\left[\text { Reduction }_{\text {(drug conc.) }}-\text { Reduction }_{\text {(negative control well) }}\right]}{\text { Reduction }_{(\text {positive control well) }}}\right)\right]} \\
& \quad \times 100
\end{aligned}
$$

where the negative control was media + Alamar Blue, but no cells and the positive control was cells + Alamar Blue, but no drug.

2.5. Analysis of Viability. At each time point, cell lines and primary AML cells were assessed for overall viability by obtaining counts on a hemocytometer slide using trypan blue exclusion dye. Percentage live and dead cells in cell lines were calculated from the raw counts. For primary cells, Percentage of survival was calculated by dividing remaining live cells by the initial cell number.

2.6. Analysis of Apoptosis. Cells were washed twice in cold DPBS and resuspended in binding buffer containing appropriate volumes of 7AAD and AnnexinV and incubated in the dark for 15 minutes at room temperature. Excess antibody/dye was washed off, and data was acquired on the flow cytometer within 1 hour of staining. Cells were evaluated on a plot of 7-AAD versus AnnexinV. Cells that stained negative for $7-\mathrm{AAD}$ and AnnexinV $\left(7 \mathrm{AAD}^{-} \mathrm{AnnexinV}^{-}\right)$were considered live and non-apoptotic/healthy. Cells that stained positive only for AnnexinV $\left(7 \mathrm{AAD}^{-} \mathrm{AnnexinV}^{+}\right)$were early apoptotic and those that stained positive for both 7-AAD and AnnexinV $\left(7 \mathrm{AAD}^{+} \mathrm{AnnexinV}^{+}\right)$were late apoptotic or necrotic. The sum of cells in the 7-AAD ${ }^{-}$Annexin $^{+}$and 7$\mathrm{AAD}^{+}$AnnexinV $V^{+}$quadrants were total dead cells.

2.7. Statistical Analysis. Data are expressed as mean values \pm SEM. Comparisons between drug treatments in cell lines were performed using the Students $t$-test, assuming equal variance. $\mathrm{IC}_{50}$ values of drugs in cell lines were determined from non-linear regression standard curve plots. In primary cells, the Mann-Whitney $U$ Rank sum test was used to determine differences between groups, and the logrank test was used to compare curves. $P \leq 0.05$ was considered significant. All statistical analyses were performed using SigmaPlot (Systat Software, Inc., Chicago, IL). 


\section{Results}

3.1. Loss of Cell Proliferation. The $\mathrm{IC}_{50}$ values, defined as the half-maximal inhibitory concentration, for ara- $\mathrm{C}$ and CNDAC in HL-60 and THP-1 cells obtained by Alamar Blue assay (Figure 1) are comparable to other published data $[13,15,18-22]$. Similarities in the chemical structure and $\mathrm{IC}_{50}$ values of ara-C and CNDAC led us to test the same doses of both drugs in cell lines and primary cells. Mitoxantrone was active at much lower doses; therefore, cells were tested at 100-fold lower doses of the drug to see effects comparable to ara-C and CNDAC. Drug dilution ranges were chosen such that it covered $\mathrm{IC}_{50}$ values. The Alamar blue assay was deemed to be inappropriate for primary cells due to the assay's dependency on cell proliferation.

3.2. Sensitivity of Cell Lines to Ara-C, CNDAC, and Mitoxantrone. To compare the effect of drugs at low and high cell proliferation rates, cell lines were plated at 2 seeding densities differing by 10-fold. HL-60 cells, plated at a high density, showed a dose response to ara-C $(0.5 \mu \mathrm{M}$ to $10 \mu \mathrm{M}$ drug $)$ with the $\%$ cell death ranging from $6.26 \pm 1.39$ to $63.8 \pm$ 5.35 on day 3 (Figure 2(b)) and $8.32 \pm 1.13$ to $86.6 \pm 6.36$ on day $6(n=3)$. However, ara-C induced higher cell death in cells plated at the lower density with $16.2 \pm 7.33$ to 94.0 $\pm 2.82 \%$ cell death on day 3 (Figure $2(\mathrm{a})$ ) and $19.6 \pm 2.88$ to $100 \pm 0.00$ on day 6 . Cell death induced by CNDAC at equivalent doses to ara-C, ranged from $17.3 \pm 3.27 \%$ to 70.2 $\pm 0.84 \%$ on day 3 (Figure $2(\mathrm{~b})$ ) to $91.7 \pm 1.02 \%$ to $95.9 \pm$ $1.01 \%$ on day 6 for cells plated at the high density, and $77.4 \pm$ $7.65 \%$ to $98.1 \pm 1.75 \%$ on day 3 (Figure $2(\mathrm{a})$ ) to $96.3 \pm 2.9 \%$ to $100 \pm 0.00 \%$ on day 6 for cells plated at the low density. At the higher cell density, although HL-60 cells showed a dose response to CNDAC on day 3 , the $\%$ of cell death was not significant until day 4 at $0.5 \mu \mathrm{M}$ and $1 \mu \mathrm{M}$ of the drug $(P \leq 0.05, n=3)$ (Figure 2(b)). At both cell densities, there was a significant increase in \% of cell death between untreated and low dose drug-treated HL-60 cells on day 4 of drug treatment $(P \leq 0.05, n=3)$. However, at lower seeding densities, equivalent concentrations of CNDAC were more effective than ara-C in inducing cell death (Figure 2(a)). The $\mathrm{IC}_{50}$ values of CNDAC, defined here as the concentration of drug required to induce $50 \%$ cell death were consistently lower than ara-C at all time points (Table 2).

THP-1 cells had a minimal response to ara-C at the high seeding density. Percentage of cell death at $10 \mu \mathrm{M}$ was $12.1 \pm$ 0.28 on day 3 (Figure $2(\mathrm{~b})$ ) and $19.7 \pm 2.31$ on day $6(n=3)$. THP-1 cells had an overall low response to CNDAC on day 3 , however, cell death was significantly higher than ara-C at doses $>2 \mu \mathrm{M}(P \leq 0.05, n=3)$. There was also a significant increase in cell death for cells treated with $\geq 2 \mu \mathrm{M}$ CNDAC on day 4 as compared to day $3(P \leq 0.05, n=3)$. The $\%$ of cell death for CNDAC-treated cells ranged from 39.9 $\pm 4.08(2 \mu \mathrm{M})$ to $54.6 \pm 3.08(10 \mu \mathrm{M})$ on day 4 and 49.8 \pm 1.55 to $86.9 \pm 2.17$ on day $6(n=3)$. Comparatively, at the lower seeding density, ara-C induced cell death at drug concentrations between $0.5 \mu \mathrm{M}$ and $10 \mu \mathrm{M}$ was highest on day $3-1.52 \pm 1.67 \%$ to $55.6 \pm 9.87 \%$ (Figure $2(\mathrm{a})$ ) and lowest on day $6-4.47 \pm 1.04 \%$ to $6.84 \pm 5.05 \%$. At this cell density, THP-1 cells showed a dose response to CNDAC by day 3 , with the $\%$ of cell death being significantly higher than ara-C at all doses tested $(P \leq 0.5, n=3$ ) (Figure 2(a)). $\mathrm{IC}_{50}$ values for CNDAC in THP-1 cells were lower than ara$\mathrm{C}$, regardless of seeding density (Table 2 ).

The $\%$ of cell death from mitoxantrone ranged from 15.9 $\pm 1.89 \%(0.0025 \mu \mathrm{M})$ to $90.8 \pm 2.72(0.05 \mu \mathrm{M})$ on day 3 (Figure $2(\mathrm{~b})$ ) and $45.3 \pm 4.67$ to $100 \pm 0.0 \%$ on day 6 for HL-60 cells plated at the higher cell density. THP-1 cells were comparatively less responsive to the drug with cell death ranging from $10.2 \pm 1.48 \%$ to $68.8 \pm 4.92 \%$ on day 3 (Figure 2 (b)) to $19.7 \pm 1.23 \%$ to $97.7 \pm 1.21 \%$ on day 6 . The $\%$ of cell death was significantly higher for cells treated with the lowest dose of mitoxantrone $(0.0025 \mu \mathrm{M})$ as compared to the untreated for HL-60 but not THP-1 cells $(P \leq 0.05$, $n=3)$. At the lower seeding density, mitoxantrone was able to induce $\geq 84.9 \pm 4.76 \%$ cell death in HL- 60 cells on day 3 and only $\geq 30.7 \pm 11.1 \%$ in THP- 1 cells at doses of $0.0025 \mu \mathrm{M}$ and above (Figure 2(a)). However, both cell lines exhibited $100 \%$ cell death at doses $>$ ss $0.0025 \mu \mathrm{M}$ of mitoxantrone.

Analysis of apoptosis was done for both cell lines at the high seeding density. Total dead cell numbers obtained from 7-AAD/Annexin $\mathrm{V}$ analysis complemented that from trypan blue counts. However, there was a difference in the distribution of early and late apoptotic events between the two cell lines. Of the total dead cells, the percent of late apoptotic/necrotic in HL-60 cells was $\leq 55.4 \pm 0.76 \%$ and for THP- 1 cells it was $\geq 58.4 \pm 0.48 \%$ for all drug treatments and time points. This is indicative of the difference in the mode of cell death between the two cell types (Figure 3).

\subsection{Sensitivity of Primary Cells from AML Patients to Ara-C,} CNDAC and Mitoxantrone. Suspension and coculture systems for primary AML PB and BM MNCs were used during the first 4 days in order to mimic in vivo conditions during drug treatment. The co-culture system postdrug wash-out was used to provide additional support for expansion of both $\mathrm{PB}$ and BM cells that evaded drug effects. Assuming $100 \%$ survival at time zero of the experiments, the survival of PB MNCs increased to $115.6 \pm 21.6 \%$ in the absence of drug when cultured in suspension during the first 4 days. Untreated BM MNCs in the co-culture system, however, had a slower growth rate with survival at $106.4 \pm 18.9 \%$ after 4 days. By day 7 of culture (cells were washed and transferred to new stromal layers on day 4), the percent survival of $\mathrm{PB}$ and BM cells was $125.91 \pm 38.7 \%$ and $130.91 \pm 35.8 \%$ respectively. There was no further cell expansion beyond day 7 as survival was $130.83 \pm 68.3 \%$ for $\mathrm{PB}$ and $129.24 \pm 55.5 \%$ for BM cells on day 35 (31 days after replating).

Primary $\mathrm{PB}$ and BM MNCs were tested at the low, medium and high doses of ara-C, CNDAC, and mitoxantrone. The lack of availability of large cell numbers limited the number of doses tested. At any analysis time point, there was no significant difference in cell survival between untreated and low-dose ara-C $(1 \mu \mathrm{M})$ treated PB cells. However, $10 \mu \mathrm{M}$ ara-C induced a significant reduction in cell survival on days 4 and 7 when compared to the untreated $(P \leq 0.05, n=5)$. Although not significant, the survival of 

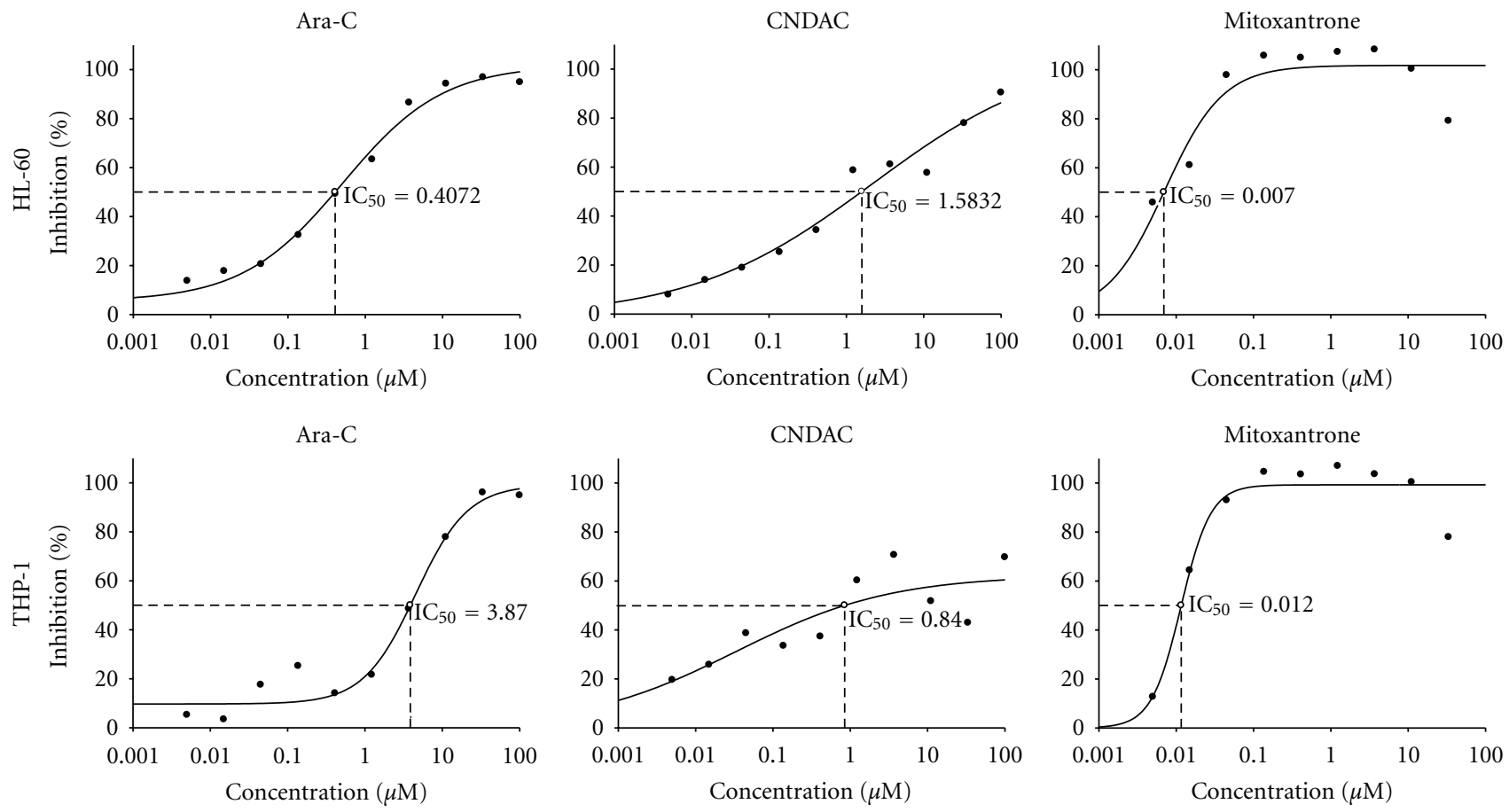

Figure 1: Standard curves and $\mathrm{IC}_{50}$ values for cell lines \pm drug treatment. Plots represent nonlinear regression standard curves and $\mathrm{IC}_{50}$ values of ara-C, CNDAC, and mitoxantrone for HL-60 (top) and THP-1 (bottom) cells as determined by Alamar Blue assay. Cells were drugtreated for 3 days and absorbance readings-taken 8 hours after addition of Alamar Blue. Inhibition (\%) of drugs was calculated from reduction (\%) of Alamar Blue. Experiments were run three times, in triplicate each time. Representative plots from one experiment are shown.

PB cells trended lower than untreated $(P=0.056 ; n=5)$ at 4 days post low-dose CNDAC treatment. By day 7, however, survival of CNDAC-treated cells at this dose was significantly lower than the untreated ( $P=0.008, n=5)$. Treatment with $10 \mu \mathrm{M}$ (medium dose) CNDAC resulted in a significant drop in cell survival compared to the untreated on days 4,7 , and 14 $(P \leq 0.05, n=5)$. On day 35 , cell survival still trended lower, but was not significant $(P=0.056 ; n=5)$ (Figure 4(a)). Low dose $(0.005 \mu \mathrm{M})$ mitoxantrone-treated cells had significantly lower cell survival on days 4 and $7(P=0.016, n=5)$ when compared to the untreated. Treatment with $0.05 \mu \mathrm{M}$ (medium dose) of mitoxantrone led to a significant loss in cell survival on all analysis days $(4,7,14$ and 35$)(P \leq 0.05$, $n=5)$. At the high dose $(100$ or $0.5 \mu \mathrm{M})$, all three drugs induced significant loss of survival of PB cells as compared to the untreated $(P \leq 0.05, n=5)$ (Figure 4(a)). The overall survival of $\mathrm{PB}$ cells treated with low -dose CNDAC, and mitoxantrone was significantly lower than the untreated throughout the 35-day culture period $(P \leq 0.05, n=5)$ (Figure 5(a)).

In the $\mathrm{BM}$ cells, the lowdose of either ara-C or CNDAC was not able to induce a significant loss in cell survival in comparison with untreated cultures at $4,7,14$, or 35-day. However, lowdose mitoxantrone treated cells exhibited a downward trend in cell survival as compared to untreated $(P=0.056 ; n=5)$. Unlike $\mathrm{PB}$, the response of BM cells to $10 \mu \mathrm{M}$ ara-C was not statistically different from the untreated controls on days 4 and $7(P=0.056$ and $P=0.69$ resp., $n=5)$. The profile of medium-dose CNDAC $(10 \mu \mathrm{M})$ and mitoxantrone $(0.05 \mu \mathrm{M})$ treated cells when compared to untreated controls was similar to that seen in the $\mathrm{PB}$ (Figure 4(b)). Reduced viability of cells treated with low dose CNDAC and mitoxantrone as compared to the untreated cells over the entire culture period was maintained in the BM cells as it was in PB cells $(P \leq 0.05, n=5)$ (Figure 5(b)).

Total cell survival in PB MNC, after 3 days of culture postdrug removal, was significantly lower for cells treated with $1 \mu \mathrm{M}$ CNDAC or $0.005 \mu \mathrm{M}$ mitoxantrone as compared to $1 \mu \mathrm{M}$ ara-C $(P \leq 0.05, n=5)$ (Figure $4(\mathrm{a}))$. A similar trend was observed with the BM MNC, but did not reach significance (Figure 4(b)). Individual patient data indicated that CNDAC had an overall greater cytotoxic effect on cells as compared to ara-C irrespective of the differences in the mutational status of patients (clinical data not shown).

\section{Discussion}

This study compared the cytotoxic effects of novel agent CNDAC to conventional agents, ara-C and mitoxantrone. The activity of ara-C and CNDAC is cell cycle dependent. Cell lines plated at low seeding densities have higher proliferation rates indicative of actively dividing cells thereby lowering $\mathrm{IC}_{50}$ 's of the drugs. Conversely, at high seeding densities, cells have lower proliferation rates thus requiring higher doses of drug to achieve similar effects (Table 2). Regardless of seeding densities, HL-60 cells were more sensitive to CNDAC than ara-C. Significant cell death is induced by CNDAC at low doses $(0.5 \mu \mathrm{M})$, indicating that 

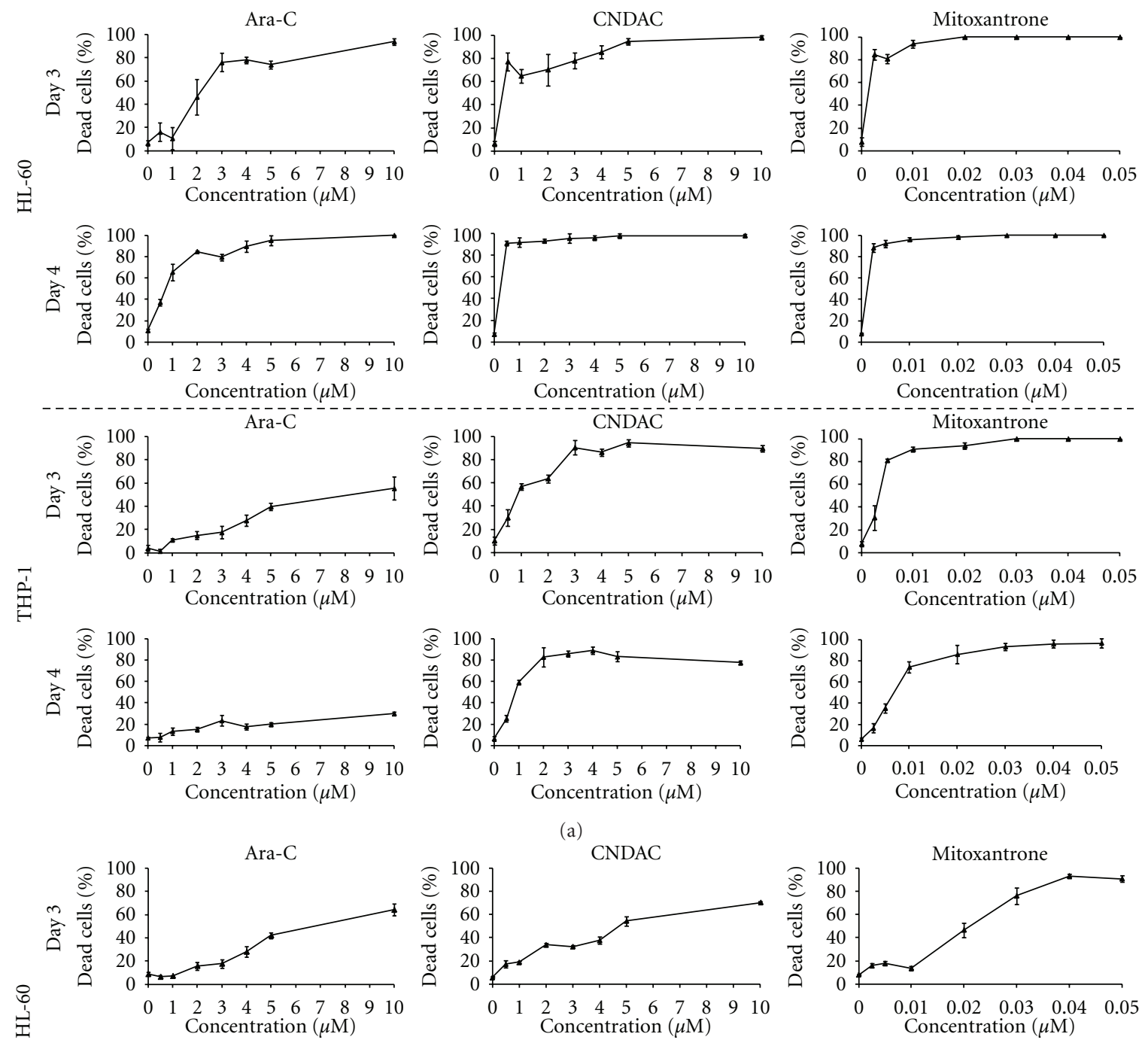

(a)
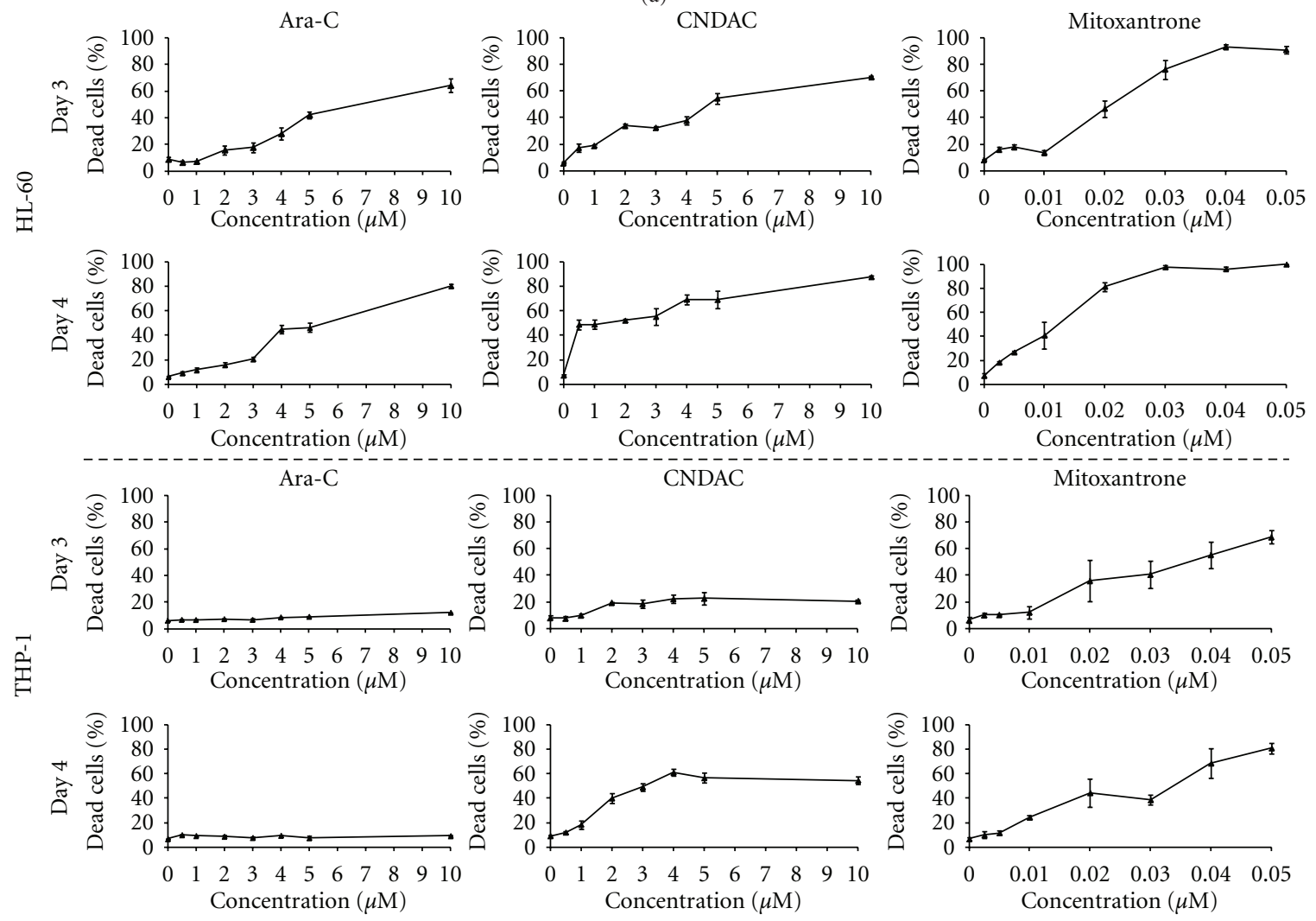

(b)

Figure 2: Viability of HL-60 and THP-1 cells \pm drug treatment. Percentage of dead HL-60 (top) and THP-1 (bottom) cells plated at (a) 0.05 $\times 10^{6}$ cells $/ \mathrm{mL}$ and (b) $0.5 \times 10^{6}$ cells $/ \mathrm{mL}$. Cells were treated with ara-C, CNDAC, and mitoxantrone in triplicate; data shown is from drug treatments for 3 and 4 days. 
TABLE 2: IC 50 values of Ara-C, CNDAC, and mitoxantrone for HL-60 and THP-1 cell lines plated at (A) $0.05 \times 10^{6}$ cells $/ \mathrm{mL}$ and $(\mathrm{B}) 0.5 \times$ $10^{6}$ cells $/ \mathrm{mL}$.

\begin{tabular}{|c|c|c|c|c|c|c|c|c|}
\hline \multicolumn{9}{|c|}{$\mathrm{IC}_{50}$ values $(\mu \mathrm{M})$} \\
\hline & \multirow{2}{*}{$\frac{\text { (A) }}{\text { Day }}$} & \multicolumn{3}{|c|}{$0.05 \times 10^{6}$ cells $/ \mathrm{mL}$} & \multirow{2}{*}{$\frac{\text { (B) }}{\text { Day }}$} & \multicolumn{3}{|c|}{$0.5 \times 10^{6}$ cells $/ \mathrm{mL}$} \\
\hline & & Ara-C & CNDAC & Mitoxantrone & & Ara-C & CNDAC & Mitoxantrone \\
\hline \multirow{4}{*}{ HL-60 } & 3 & 2.099 & $<0.5$ & $<0.0025$ & 3 & 6.157 & 5.356 & 0.021 \\
\hline & 4 & 0.692 & $<0.5$ & $<0.0025$ & 4 & 5.031 & 1.149 & 0.011 \\
\hline & 5 & 0.964 & $<0.5$ & $<0.0025$ & 5 & 5.503 & $<0.5$ & 0.008 \\
\hline & 6 & 1.929 & $<0.5$ & $<0.0025$ & 6 & 5.946 & $<0.5$ & 0.003 \\
\hline \multirow{4}{*}{ THP-1 } & 3 & 7.771 & 0.929 & 0.003 & 3 & $>10$ & $>10$ & 0.035 \\
\hline & 4 & $>10$ & 0.816 & 0.006 & 4 & $>10$ & 2.774 & 0.030 \\
\hline & 5 & $>10$ & 1.105 & 0.011 & 5 & $>10$ & 2.434 & 0.017 \\
\hline & 6 & $>10$ & 1.104 & 0.007 & 6 & $>10$ & 2.095 & 0.012 \\
\hline
\end{tabular}

higher doses are unnecessary. A low effective dose is highly desired in the clinical setting, as low doses usually equate to less toxicity and meylosuppression in patients.

THP-1 cells are known to be less sensitive to ara$\mathrm{C}$ due to high cytidine deaminase (CDA) activity, which deaminates ara-C into the inactive ara- $\mathrm{U}[7,8,18]$. It is also shown to release the enzyme into the culture media thus deactivating the drug [18]. Ara-C was found to be active in these cells when plated at a low density albeit at very high concentrations $\left(\mathrm{IC}_{50}=7.7 \mu \mathrm{M}\right)$. Higher cell death for araC-treated THP-1 cells on day 3 compared to day 6 , when plated at the low density, can be explained by increasing amounts of CDA in the culture media resulting from active proliferation of cells. At the high seeding density, an $\mathrm{IC}_{50}$ for the drug in THP-1 cells was not achievable at the doses tested, perhaps due to complete inactivation of ara-C by CDA. THP-1 cells, however, responded to CNDAC with IC $_{50}$ values $\leq 2.774 \mu \mathrm{M}$, regardless of cell density (Table 2). The $\mathrm{IC}_{50}$ has been shown to be around $1 \mu \mathrm{M}$ in tumor cell lines [14] and mice [16]. Also, PK studies in humans have detected concentrations of CNDAC in plasma upwards of $0.25 \mu \mathrm{M}$ [2]. Together, these studies indicate that the data generated here is comparable to other studies and is likely clinically relevant. CNDAC is known to be a poor substrate for CDA, [16] thus explaining CNDAC's similar activity at both cell densities. Interestingly, CNDAC appears to have a delayed effect on THP-1 cells as a modest effect is seen on day 3 with a more robust effect seen on days 4-6 (Table 2 and Figure 2(a)). Mitoxantrone was largely unaffected by the seeding densities of cells. Although mitoxantrone has activity in both proliferating and nonproliferating cells, it is more active in cells in division than those in the latent phase [23]. This is evident in our experiments from the larger $\mathrm{IC}_{50}$ values seen at the higher cell densities and vice versa. Higher IC $_{50}$ values for THP-1, compared to HL-60, suggest that THP- 1 cells are slightly more resistant to mitoxantrone than HL-60 cells.

Stromal cells are often thought of as sanctuaries for primary leukemic cells. They produce cytokines and growth factors that protect cells in their niche and influence their proliferation, differentiation, and survival [24-26]. The immortalized human stromal cell line, HS-5, has been shown to protect AML cells from the toxic effects of ara-C $[27,28]$.
M2-10B4 feeder layers have been used in long-term culture initiating cell (LTC-IC) and cobblestone area forming cell (CAFC) assays and are known to provide antiapoptotic signals to both healthy and leukemic human and murine cells when cultured in contact [29-31]. The use of M2-10B4 coculture systems to evaluate drug effects in primary cells from AML patients has not been reported previously. The culture system used in this study therefore provides a unique drug evaluation tool not limited to AML.

In our experiments, while $\mathrm{PB}$ cells seemed more sensitive to effects of drugs, a fraction of BM cells was protected from toxic effects as they were treated with drug in the presence of stroma. At the low and middle doses, both $\mathrm{PB}$ and $\mathrm{BM}$ cells treated with ara-C seemed to grow out post drug removal with the support of the stromal cells (Figure 4). However, the outgrowth of BM cells was higher, indicating that stromal cells do not largely support the growth of PB cells. Contrastingly, there was a continuous loss of PB and BM MNCs treated with medium, and high doses of mitoxantrone as the cells cultured, suggestive of the longer effect of the drug even after washout. Additional studies which test the leukemic potential of the AML cells, that grow out postdug treatment, in immunodeficient mouse model systems are warranted.

Unlike Ara-C treated cells, the residual cells, in both $\mathrm{BM}$ and $\mathrm{PB}$ after CNDAC-treatment, did not expand in culture. 2' - C-cyano- $2^{\prime}, 3^{\prime}$-didehydro-2', $3^{\prime}$-dideoxycytidine $(\mathrm{CNddC})$, the chain terminating $\beta$ elimination intermediate of CNDAC, is a poor substrate for DNA chain elongation and is responsible for inducing DNA single strand breaks. It is known to have a long shelf life in whole cells and its removal by the nucleotide repair (NER) mechanism is thought to be a slow process [17]. This unique mechanism therefore induces a prolonged effect on the survival of CNDAC treated cells.

Our experiments have shown CNDAC to be more active than ara-C in both primary cells and cell lines. Sapacitabine is the palmitoyl derivative of CNDAC. The palmitoyl chain allows for oral absorption of the drug and protects the N4 amino group from deamination. A comparison of CNDAC and sapacitabine is presented by Serova et al. [15] The data presented here suggests that sapacitabine may be able to be administrated effectively to patients at lower 

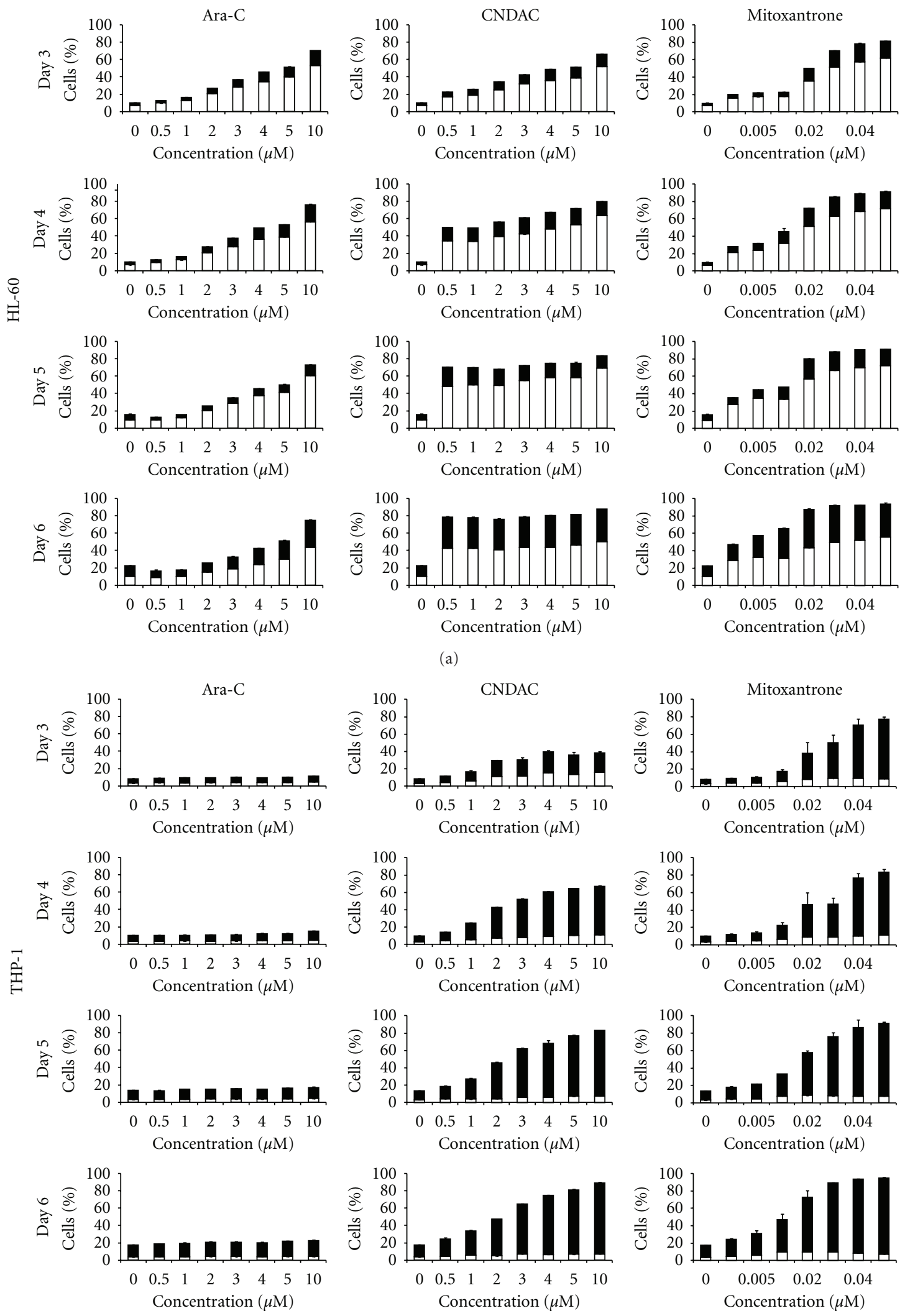

(b)

Figure 3: Apoptosis analysis of HL-60 and THP-1 cells. Plots represent distribution of $\square \%$ early and $\square$ \% late apoptotic (a) HL-60 and (b) THP-1 cells treated with ara-C, CNDAC, or mitoxantrone as determined by $7-\mathrm{AAD} /$ Annexin V staining. Cells were plated at $0.5 \times 10^{6}$ cells $/ \mathrm{mL}$, in triplicate, and drug-treated for 3, 4, 5, and 6 days. The entire bar represents total dead cells. 

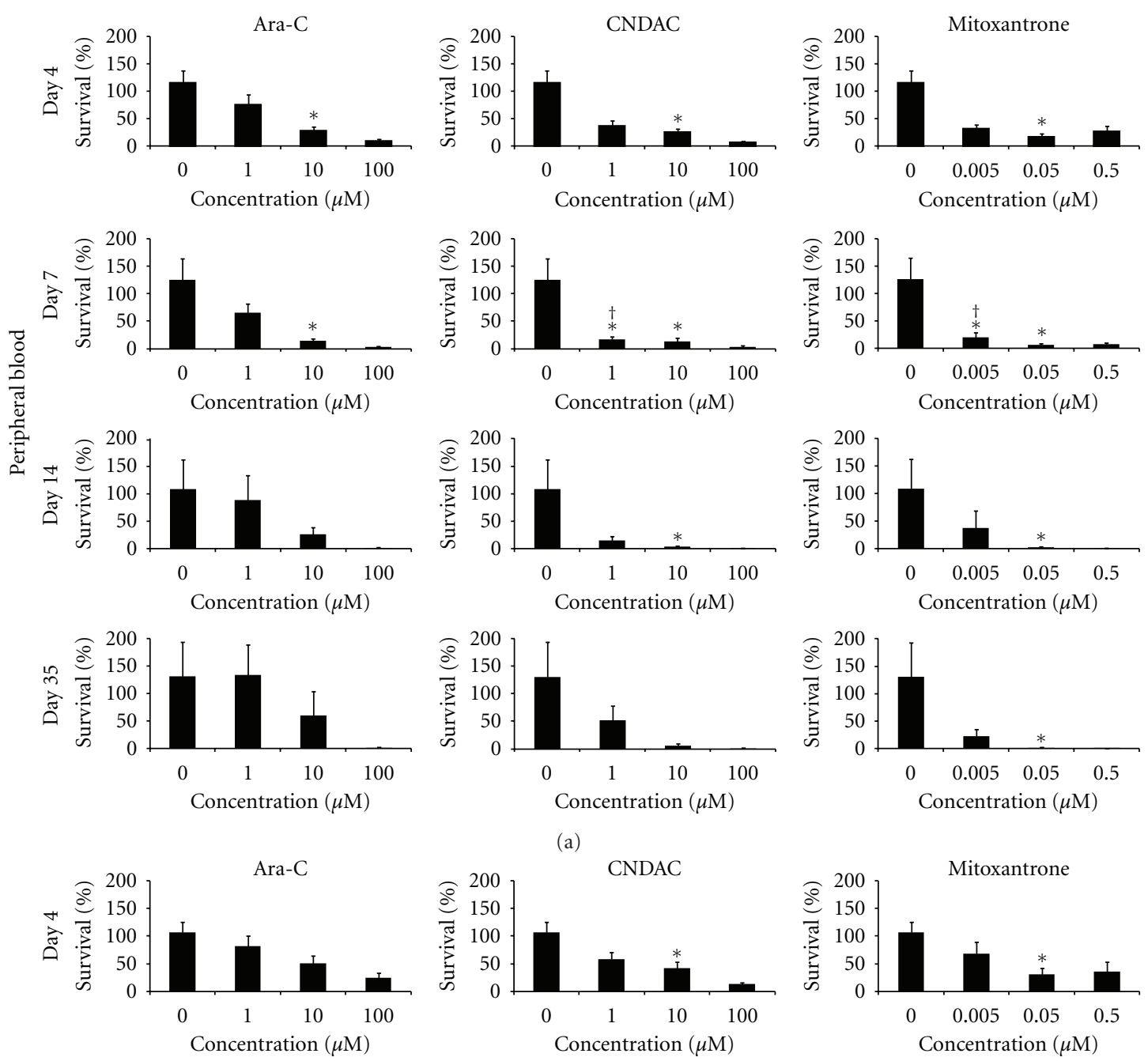

(a)
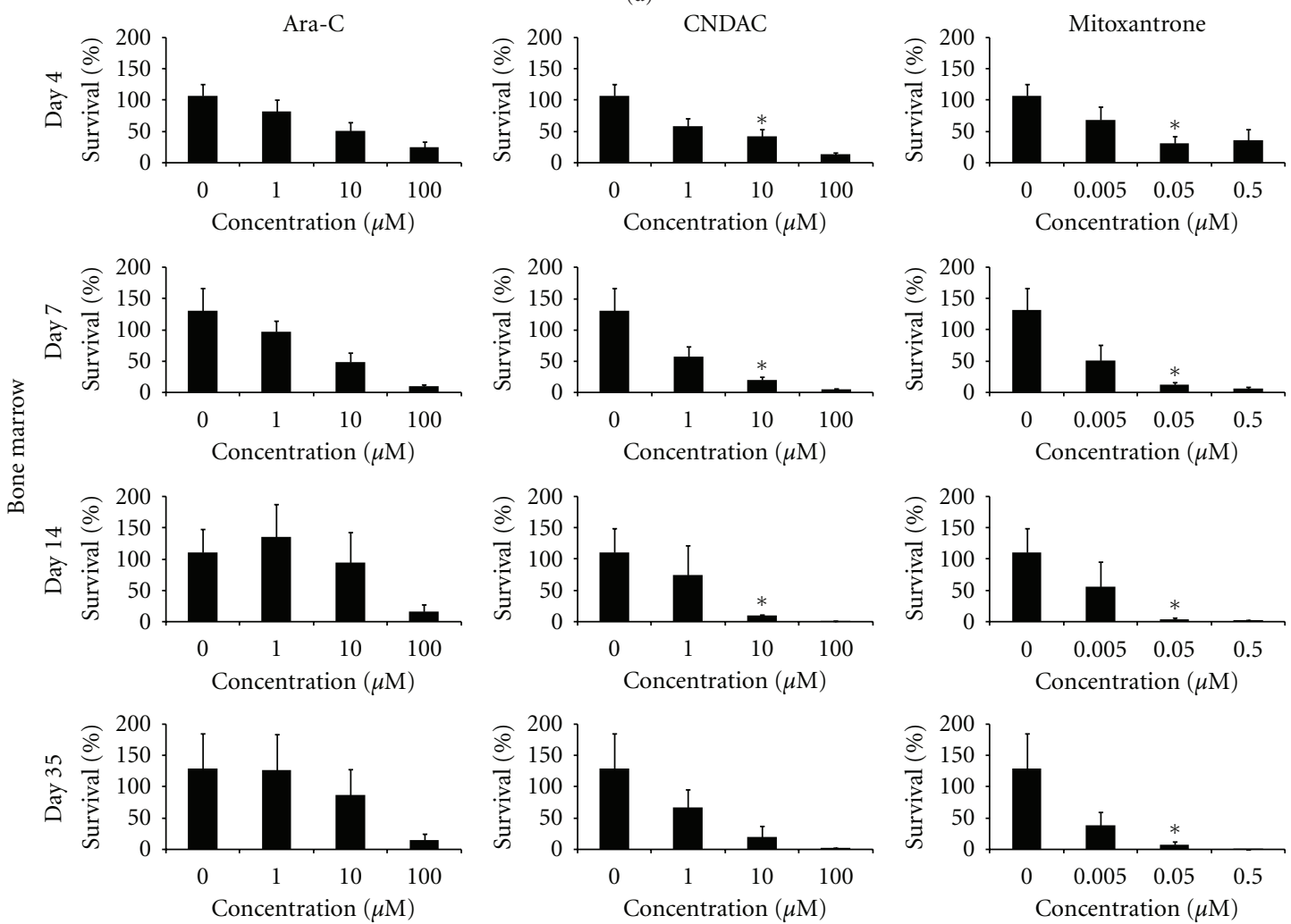

(b)

Figure 4: AML MNC \pm drug treatment. Percentages survival (relative to number of cells plated) calculated from hemocytometer counts using trypan blue for (a) AML PB MNCs and (b) AML BM MNCs ( $n=5$ patients) treated with ara-C, CNDAC or mitoxantrone are shown. PB MNCs were drug-treated in suspension, while BM MNCs were treated in the presence of M2-10B4 stromal layers for 4 days (Day 4). Cells were then washed and replated on M2-10B4 stromal layers for post-drug wash-out analysis on days 7,14 , and 35 . * denotes $P \leq 0.05$ for particular drug concentrations compared with untreated, and ${ }^{\dagger}$ denotes $P \leq 0.05$ for $1 \mu \mathrm{M}$ CNDAC or $0.005 \mu \mathrm{M}$ mitoxantrone compared to $1 \mu \mathrm{M}$ ara-C. 


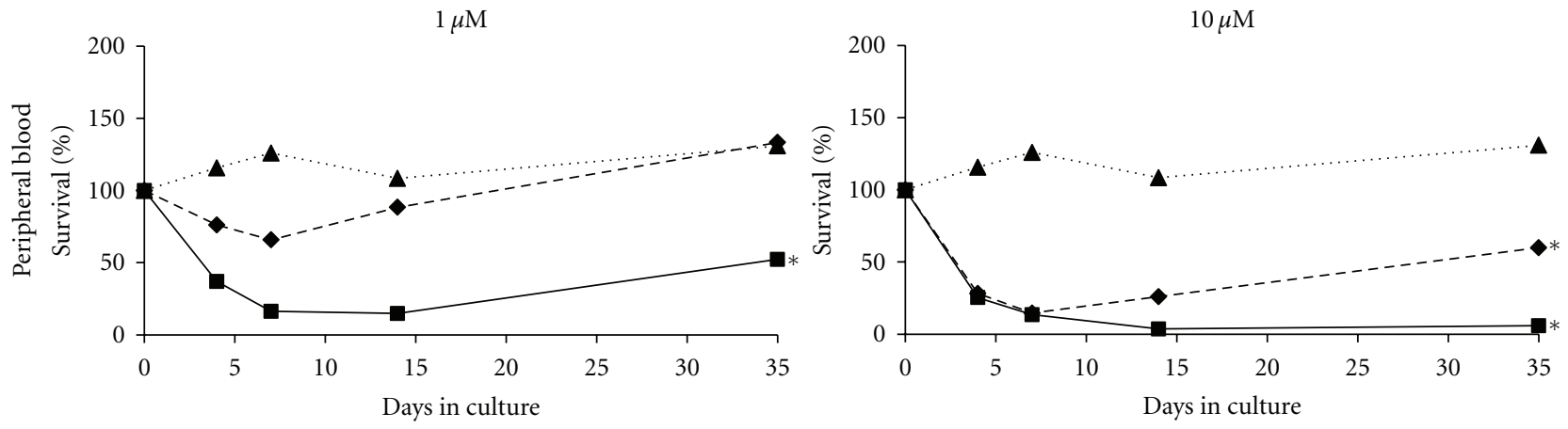

(a)
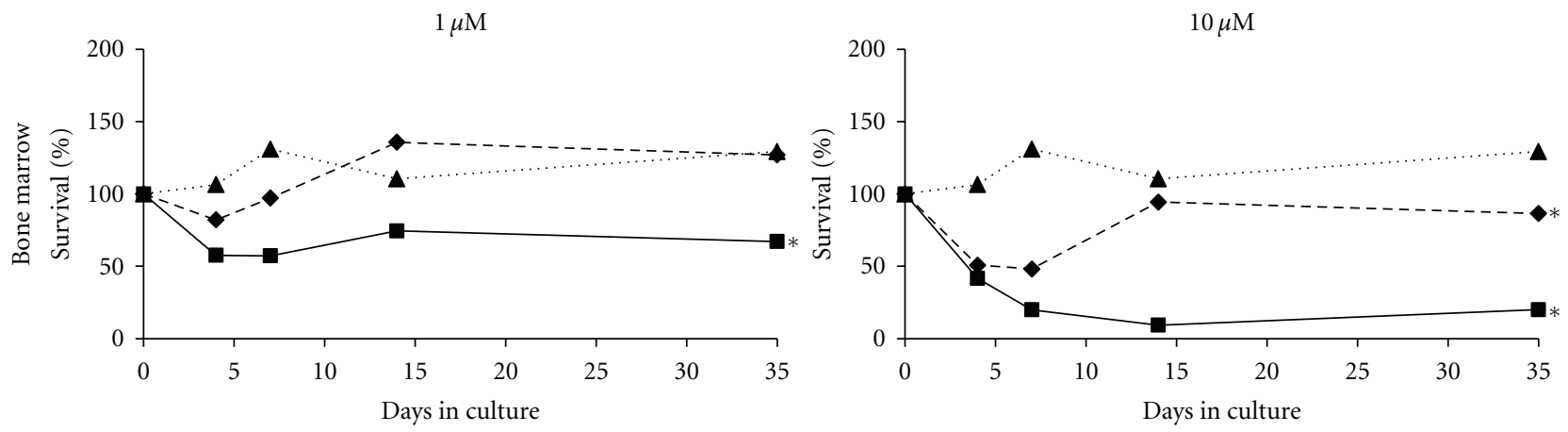

(b)

Figure 5: Growth of AML MNC \pm drug treatment. Growth of untreated (.... dotted line), Ara-C treated (- - - dashed line) or CNDAC treated (- solid line) (a) PB and (b) BM AML cells from patients over the 35 day culture period, plotted as \% survival relative to the number of cells initially plated. Drug treatment concentrations plotted are at $1 \mu \mathrm{M}$ and $10 \mu \mathrm{M}$. ${ }^{*}$ denotes $P \leq 0.05$ as determined by the log rank test as compared to the survival curve of untreated cells.

doses than currently done; thus minimizing drug induced myelosuppression and toxicity to normal tissues. CNDAC has also been shown to be more active than ara-C in vivo in a P388 mouse leukemia model $[32,33]$. Activity of CNDAC at low doses in THP- 1 cells suggests its use as an alternative treatment option in patients resistant to ara-C.

On the clinical front, sapacitabine has shown promising antileukemic activity. Phase I trials demonstrated the drug to be safe and active in the treatment of certain hematologic disorders (MDS and AML) and solid tumors alike [34]. It is also effective in AML and MDS patients with poor prognosis [2]. Sapacitabine is currently in Phase III trial for newly diagnosed AML patients who are 70 years or older and not a candidate for intensive induction therapy.

Future studies are warranted to assess the potential of combining CNDAC in the upfront setting of AML either simultaneously or in sequence with standard chemotherapy; particularly in patients who do not respond to ara-Cbased therapies. There is a lifetime limit for the administration of mitoxantrone to patients as its toxicity is accumulative [35]. CNDAC, however, has no lifetime limit, making it a good candidate for maintenance therapy. In view of the low-toxicity profile, it is likely to be tolerated and a meaningful improvement in response can be expected.

\section{Authors' Contribution}

K.W.C. conceived and designed the research project; S.J., L.A.P. and R.R.F. designed and performed research experiments; S.J., L.A.P., P.V., M.L. and K.W.C., analyzed and interpreted data and wrote the manuscript.

\section{Conflict of Interests}

All authors declare that they have no competing financial interests.

\section{Acknowledgments}

The authors thank Cyclacel Ltd. for kindly providing CNDAC. They also thank Dr. Sefer Gezer, from Rush University Medical Center, for collection of bone marrow aspirates; Sheelagh Frame, fom Cyclacel, for intellectual contributions. This work was primarily supported by the Taylor Chair to PV. KWC was also supported during this research period by grants from the NIH-National Institute of Diabetes and Digestive and Kidney Diseases (DK074892), American Association for Cancer Research (07-10-19-CHRI), the Leukemia and Lymphoma Society (6044-08), the Rush Translational Sciences Consortium (08102761), National Blood Foundation/American Association of Blood Banks (031824), the 
Paul A and Joan S Rubschlager Foundation, and the Coleman Foundation (5008).

\section{References}

[1] W. Kern and E. H. Estey, "High-dose cytosine arabinoside in the treatment of acute myeloid leukemia: review of three randomized trials," Cancer, vol. 107, no. 1, pp. 116-124, 2006.

[2] H. Kantarjian, G. Garcia-Manero, S. O'Brien et al., "Phase I clinical and pharmacokinetic study of oral sapacitabine in patients with acute leukemia and myelodysplastic syndrome," Journal of Clinical Oncology, vol. 28, no. 2, pp. 285-291, 2010.

[3] M. S. Tallman, D. G. Gilliland, and J. M. Rowe, "Drug therapy for acute myeloid leukemia," Blood, vol. 106, no. 4, pp. 11541163, 2005.

[4] K. F. Bradstock, J. P. Matthews, R. M. Lowenthal et al., "A randomized trial of high- versus conventional-dose cytarabine in consolidation chemotherapy for adult de novo acute myeloid leukemia in first remission after induction therapy containing high-dose cytarabine," Blood, vol. 105, no. 2, pp. 481-488, 2005.

[5] F. Ravandi, H. Kantarjian, F. Giles, and J. Cortes, "New agents in acute myeloid leukemia and other myeloid disorders," Cancer, vol. 100, no. 3, pp. 441-454, 2004.

[6] E. Estey and H. Dohner, "Acute myeloid leukaemia," The Lancet, vol. 368, no. 9550, pp. 1894-1907, 2006.

[7] S. Grant, "Ara-C: cellular and molecular pharmacology," Advances in Cancer Research, vol. 72, pp. 197-233, 1997.

[8] C. M. Galmarini, J. R. Mackey, and C. Dumontet, "Nucleoside analogues: mechanisms of drug resistance and reversal strategies," Leukemia, vol. 15, no. 6, pp. 875-890, 2001.

[9] C. M. Galmarini, X. Thomas, F. Calvo et al., "Potential mechanisms of resistance to cytarabine in AML patients," Leukemia Research, vol. 26, no. 7, pp. 621-629, 2002.

[10] E. J. Fox, "Mechanism of action of mitoxantrone," Neurology, vol. 63, no. 12, supplement 6, pp. S15-S18, 2004.

[11] K. Bhalla, A. M. Ibrado, E. Tourkina et al., "High-dose mitoxantrone induces programmed cell death or apoptosis in human myeloid leukemia cells," Blood, vol. 82, no. 10, pp. 3133-3140, 1993.

[12] K. M. Rentsch, D. H. Horber, R. A. Schwendener, H. WunderliAllenspach, and E. Hänseler, "Comparative pharmacokinetic and cytotoxic analysis of three different formulations of mitoxantrone in mice," British Journal of Cancer, vol. 75, no. 7, pp. 986-992, 1997.

[13] A. Azuma, P. Huang, A. Matsuda, and W. Plunkett, " 2 ' C-cyano-2' -deoxy-1- $\beta$-D-arabino-pentofuranosylcytosine: a novel anticancer nucleoside analog that causes both DNA strand breaks and G2 arrest," Molecular Pharmacology, vol. 59, no. 4, pp. 725-731, 2001.

[14] A. Azuma, P. Huang, A. Matsuda, and W. Plunkett, "Cellular pharmacokinetics and pharmacodynamics of the deoxycytidine analog 2'-C-cyano-2'-deoxy-1- $\beta$-D-arabinopentofuranosylcytosine (CNDAC)," Biochemical Pharmacology, vol. 61, no. 12, pp. 1497-1507, 2001.

[15] M. Serova, C. M. Galmarini, A. Ghoul et al., "Antiproliferative effects of sapacitabine (CYC682), a novel 2'-deoxycytidinederivative, in human cancer cells," British Journal of Cancer, vol. 97, no. 5, pp. 628-636, 2007.

[16] K. Hanaoka, M. Suzuki, T. Kobayashi et al., "Antitumor activity and novel DNA-self-strand-breaking mechanism of CNDAC (1-(2-C-cyano-2-deoxy- $\beta$-D-arabino-pentofuranosyl) cytosine) and its $\mathrm{N}^{4}$-palmitoyl derivative (CS-682),"
International Journal of Cancer, vol. 82, no. 2, pp. 226-236, 1999.

[17] Y. Wang, X. Liu, A. Matsuda, and W. Plunkett, "Repair of 2' C-cyano-2'-deoxy-1- $\beta$-D-arabino- pentofuranosylcytosineinduced DNA single-strand breaks by transcription-coupled nucleotide excision repair," Cancer Research, vol. 68, no. 10, pp. 3881-3889, 2008.

[18] Y. Ge, T. L. Jensen, M. L. Stout et al., "The role of cytidine deaminase and GATA1 mutations in the increased cytosine arabinoside sensitivity of Down syndrome myeloblasts and leukemia cell lines," Cancer Research, vol. 64, no. 2, pp. 728735, 2004.

[19] H. Gourdeau, L. Bibeau, F. Ouellet, D. Custeau, L. Bernier, and T. Bowlin, "Comparative study of a novel nucleoside analogue (Troxatyl, troxacitabine, $\mathrm{BCH}-4556$ ) and AraC against leukemic human tumor xenografts expressing high or low cytidine deaminase activity," Cancer Chemotherapy and Pharmacology, vol. 47, no. 3, pp. 236-240, 2001.

[20] X. B. Kong, W. P. Tong, and T. C. Chou, "Induction of deoxycytidine kinase by 5-azacytidine in an HL-60 cell line resistant to arabinosylcytosine," Molecular Pharmacology, vol. 39, no. 2, pp. 250-257, 1991.

[21] T. Qin, E. M. Youssef, J. Jelinek et al., "Effect of cytarabine and decitabine in combination in human leukemic cell lines," Clinical Cancer Research, vol. 13, no. 14, pp. 4225-4232, 2007.

[22] W. Fiskus, R. Rao, P. Fernandez et al., "Molecular and biologic characterization and drug sensitivity of pan-histone deacetylase inhibitor resistant acute myeloid leukemia cells," Blood, vol. 112, no. 7, pp. 2896-2905, 2008.

[23] C. M. Li, X. G. Liu, X. C. Lin, X. W. Chen, and N. C. Liang, "Effects of mitoxantrone on the activity of human protein kinase CK2 holoenzyme," Chinese Journal of Cancer, vol. 27, no. 8, pp. 809-815, 2008.

[24] W. S. Dalton, L. Hazlehurst, K. Shain, T. Landowski, and M. Alsina, "Targeting the bone marrow microenvironment in hematologic malignancies," Seminars in Hematology, vol. 41, supplement 2, part 4, pp. 1-5, 2004.

[25] Z.-W. Li and W. S. Dalton, "Tumor microenvironment and drug resistance in hematologic malignancies," Blood Reviews, vol. 20, no. 6, pp. 333-342, 2006.

[26] M. B. Meads, L. A. Hazlehurst, and W. S. Dalton, "The bone marrow microenvironment as a tumor sanctuary and contributor to drug resistance," Clinical Cancer Research, vol. 14, no. 9, pp. 2519-2526, 2008.

[27] S. M. Garrido, F. R. Appelbaum, C. L. Willman, and D. E. Banker, "Acute myeloid leukemia cells are protected from spontaneous and drug-induced apoptosis by direct contact with a human bone marrow stromal cell line (HS-5)," Experimental Hematology, vol. 29, no. 4, pp. 448-457, 2001.

[28] B. Moshaver, M. van der Pol, A. Westra, G. Ossenkoppele, S. Zweegman, and G. J. Schuurhuis, "Chemotherapeutic treatment of bone marrow stromal cells strongly affects their protective effect on acute myeloid leukemia cell survival," Leukemia and Lymphoma, vol. 49, no. 1, pp. 134-148, 2008.

[29] D. G. Bouzianas, "Cobblestone area measuring (CAM) assay: a new way of assessing the potential of human haemopoietic stem cells," Methods in Cell Science, vol. 25, no. 3-4, pp. 201210, 2003.

[30] J. Edelmann, L. Klein-Hitpass, A. Carpinteiro et al., "Bone marrow fibroblasts induce expression of PI3K/NF- $\kappa \mathrm{B}$ pathway genes and a pro-angiogenic phenotype in CLL cells," Leukemia Research, vol. 32, no. 10, pp. 1565-1572, 2008.

[31] B. Nervi, P. Ramirez, M. P. Rettig et al., "Chemosensitization of acute myeloid leukemia (AML) following mobilization by 
the $\mathrm{CXCR}_{4}$ antagonist AMD3100," Blood, vol. 113, no. 24, pp. 6206-6214, 2009.

[32] A. Matsuda, Y. Nakajima, A. Azuma, M. Tanaka, and T. Sasaki, "Nucleosides and nucleotides. 100. 2'-C-cyano-2'-deoxy-1- $\beta$ $\mathrm{D}$-arabinofuranosyl-cytosine (CNDAC): design of a potential mechanism-based DNA-strand-breaking antineoplastic nucleoside," Journal of Medicinal Chemistry, vol. 34, no. 9, pp. 2917-2919, 1991.

[33] M. Tanaka, A. Matsuda, T. Terao, and T. Sasaki, "Antitumor activity of a novel nucleoside, 2 '-C-cyano-2' -deoxy-1$\beta$-D-arabinofuranosylcytosine (CNDAC) against murine and human tumors," Cancer Letters, vol. 64, no. 1, pp. 67-74, 1992.

[34] J. Gilbert, M. A. Carducci, S. D. Baker, E. C. Dees, and R. Donehower, "A Phase I study of the oral antimetabolite, CS682, administered once daily 5 days per week in patients with refractory solid tumor malignancies," Investigational New Drugs, vol. 24, no. 6, pp. 499-508, 2006.

[35] G. Edan, S. Morrissey, and E. Le Page, "Rationale for the use of mitoxantrone in multiple sclerosis," Journal of the Neurological Sciences, vol. 223, no. 1, pp. 35-39, 2004. 


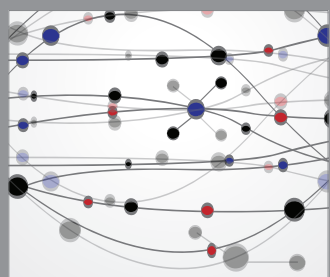

The Scientific World Journal
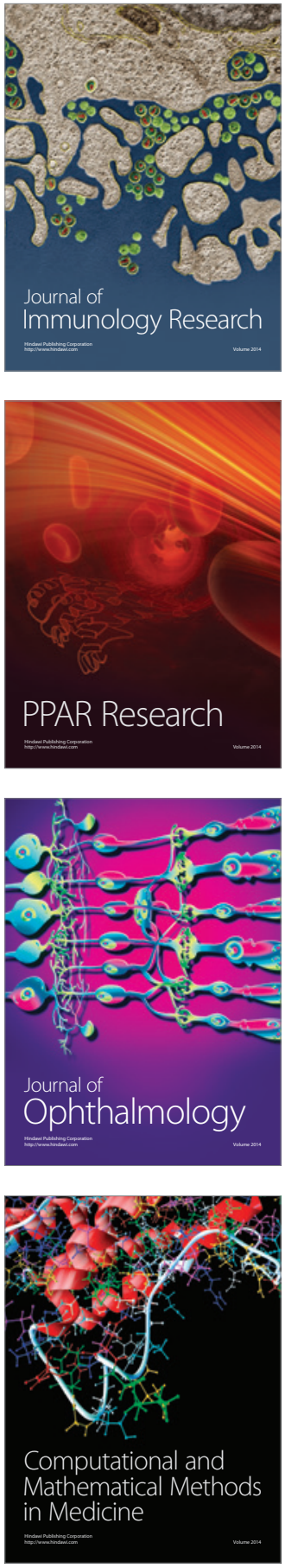

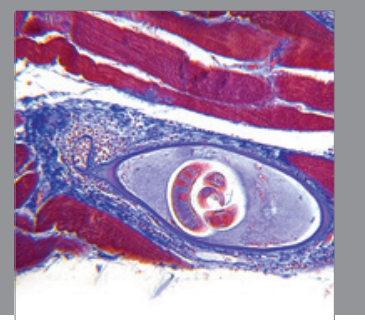

Gastroenterology

Research and Practice
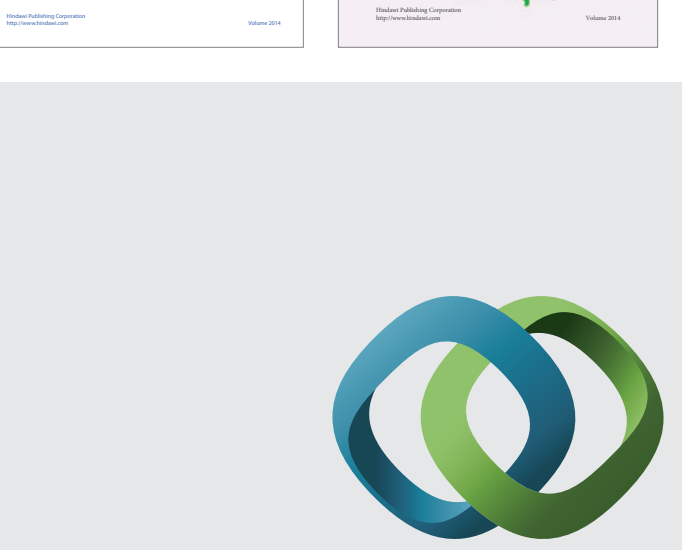

\section{Hindawi}

Submit your manuscripts at

http://www.hindawi.com
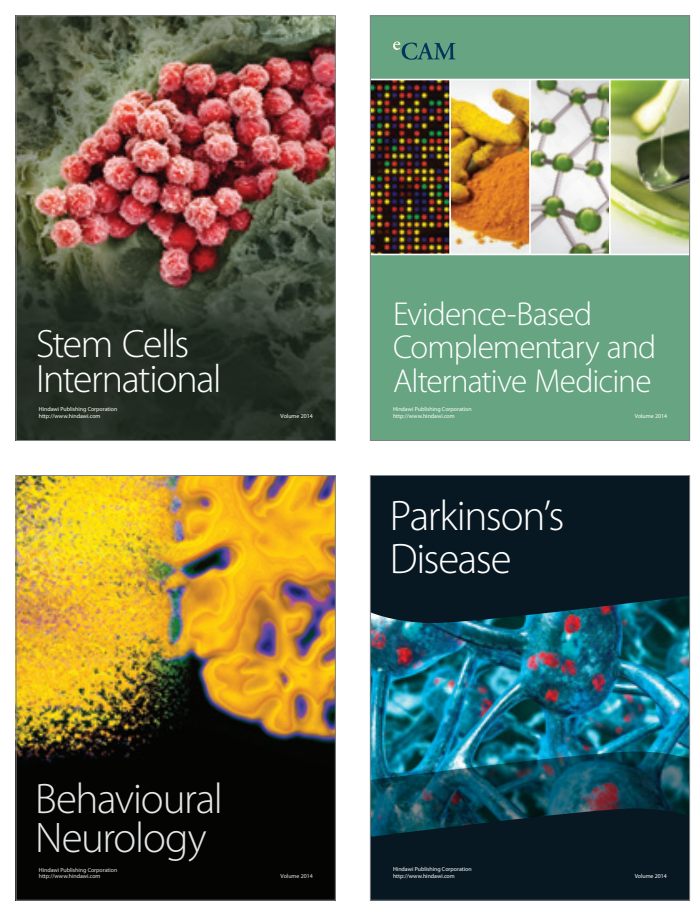

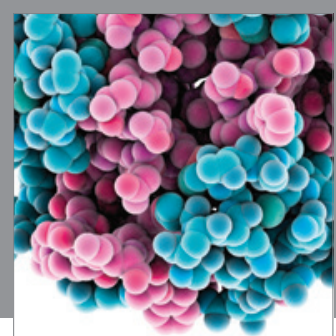

Journal of
Diabetes Research

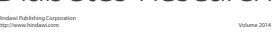

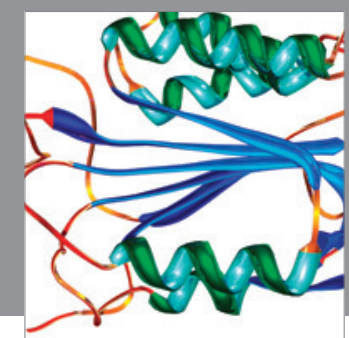

Disease Markers
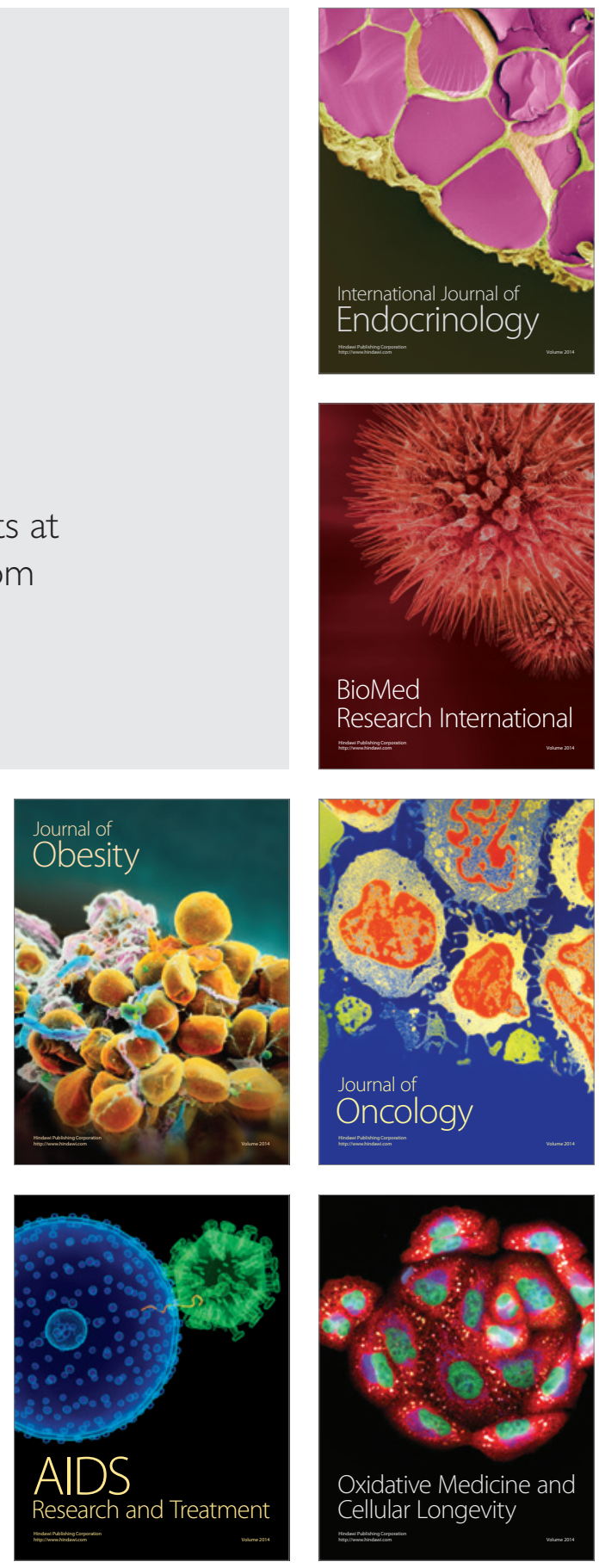